\title{
Review
}

\section{The Functions of the Demethylase JMJD3 in Cancer}

\author{
Anna Sanchez 1,2@, Fatma Zohra Houfaf Khoufaf ${ }^{1,2}$, Mouhamed Idrissou ${ }^{1,2}$, Frédérique Penault-Llorca ${ }^{2,3}$, \\ Yves-Jean Bignon ${ }^{1,2}$, Laurent Guy ${ }^{2,4}$ and Dominique Bernard-Gallon ${ }^{1,2, *}$ \\ 1 Department of Oncogenetics, Centre Jean Perrin, CBRV, 63001 Clermont-Ferrand, France; \\ anna.sanchez@etu.uca.fr (A.S.); houfaf.fz@gmail.com (F.Z.H.K.); mouhamed.idrissou@etu.uca.fr (M.I.); \\ Yves-Jean.BIGNON@clermont.unicancer.fr (Y.-J.B.) \\ 2 INSERM U 1240 Molecular Imagery and Theranostic Strategies (IMOST), 63005 Clermont-Ferrand, France; \\ Frederique.PENAULT-LLORCA@clermont.unicancer.fr (F.P.-L.); lguy@chu-clermontferrand.fr (L.G.) \\ 3 Department of Biopathology, Centre Jean Perrin, 63011 Clermont-Ferrand, France \\ 4 Department of Urology, Gabriel Montpied Hospital, 63000 Clermont-Ferrand, France \\ * Correspondence: dominique.gallon-bernard@clermont.unicancer.fr
}

Citation: Sanchez, A.; Houfaf

Khoufaf, F.Z.; Idrissou, M.

Penault-Llorca, F.; Bignon, Y.-J.; Guy,

L.; Bernard-Gallon, D. The Functions of the Demethylase JMJD3 in Cancer. Int. J. Mol. Sci. 2021, 22, 968. https:// doi.org/10.3390/ijms22020968

Academic Editor: Maria M. Sasiadek Received: 19 November 2020

Accepted: 15 January 2021

Published: 19 January 2021

Publisher's Note: MDPI stays neutral with regard to jurisdictional claims in published maps and institutional affiliations.

Copyright: (C) 2021 by the authors Licensee MDPI, Basel, Switzerland. This article is an open access article distributed under the terms and conditions of the Creative Commons Attribution (CC BY) license (https:// creativecommons.org/licenses/by/ $4.0 /)$.

\begin{abstract}
Cancer is a major cause of death worldwide. Epigenetic changes in response to external (diet, sports activities, etc.) and internal events are increasingly implicated in tumor initiation and progression. In this review, we focused on post-translational changes in histones and, more particularly, the tri methylation of lysine from histone 3 (H3K27me3) mark, a repressive epigenetic mark often under- or overexpressed in a wide range of cancers. Two actors regulate H3K27 methylation: Jumonji Domain-Containing Protein 3 demethylase (JMJD3) and Enhancer of zeste homolog 2 (EZH2) methyltransferase. A number of studies have highlighted the deregulation of these actors, which is why this scientific review will focus on the role of JMJD3 and, consequently, H3K27me3 in cancer development. Data on JMJD3's involvement in cancer are classified by cancer type: nervous system, prostate, blood, colorectal, breast, lung, liver, ovarian, and gastric cancers.
\end{abstract}

Keywords: JMJD3; cancers; H3K27me3; epi-drugs

\section{Introduction}

At present, cancer is a major cause of death worldwide. There were 18.1 million new cases and 9.6 million deaths caused by cancer in 2018. About one in five men and one in six women will develop the disease during their lifetime [1].

The reasons behind the development of cancer are many and varied. Cancer can be sporadically caused by a spontaneous mutation in the DNA sequence, and the risk factors cannot be determined with certainty. There are a number of other risk factors that can lead to the formation of cancer. We classify these factors into two groups: intrinsic factors, including age, hormonal status, and family history and extrinsic factors affecting the individual's environment and lifestyle, such as diet, physical activity frequency, and hormonal contraceptive use (National Cancer Institute, Bethesda in Maryland (MD), United States). Epigenetics are influenced by external or internal environmental factors, such as the specific characteristics of the cell, and play a major role in oncogenesis by modulating chromatin compaction and, consequently, the expression of some genes involved in tumor development [2].

Epigenetics can be defined as the modification of gene expression without modification of the DNA sequence. These epigenetic variations are reversible and transmissible to one's descendants. The epigenetic mechanisms involved are the action of non-coding RNAs (ncRNAs), such as small RNAs, micro RNAs (miRNAs), PIWI-interacting RNAs (piRNAs), endogenous short RNAs (endo-siRNAs), and long non-coding RNAs (lnRNAs)) [3]. DNA methylation and the covalent post-translational modifications (PTMs) of histones, among which acetylation and methylation are the most studied. Epigenetic 
modifications contribute to changes in chromatin compaction and are widely studied in cancerology [4-6].

Epigenetic mechanisms are controlled by the action of actors capable of reading, erasing, or writing epigenetic modifications [7,8]. This review focuses on the involvement of the jumonji domain-containing protein 3 demethylase (JMJD3) - whose role is to demethylate the di- and tri-methylation of lysine 27 from histone 3 (H3K27me3), a repressive epigenetic mark-in various cancers $[9,10]$.

\section{Results}

\subsection{Post-Translational Modification of Histones}

PTMs of histones are known to lead to changes in the structure of chromatin [11]. Chromatin is composed of a repetition of nucleosomes, which contain $\sim 147 \mathrm{pb}$ of DNA wrapped around an octamer of histones $(2 \mathrm{H} 2 \mathrm{~A}, 2 \mathrm{H} 2 \mathrm{~B}, 2 \mathrm{H} 3$, and $2 \mathrm{H} 4)$, wherein $\mathrm{H} 1$ has the role of locking the nucleosomal structure. Chromatin is composed of DNA, small histone basic proteins, and non-histone proteins involved in replication and transcription. The nucleosome is the primary level of DNA condensation and the fundamental unit of chromatin's structure [7,12].

Histones are basic proteins that are highly conserved during evolution and have three $\alpha$ helices-a structure called a "histone fold". These $\alpha$ helices are connected to each other by loops called L1 and L2 [13]. These basic proteins have a C-terminal tail, located in the center of the histone octamer, and an $N$-terminal tail that is often enriched with lysine (K) and arginine (R), which can undergo PTMs. PTMs of the $N$-terminal histone tails allow for the regulation of gene expression by modifying chromatin compaction and access to DNA by transcription factors [11].

PTMs are varied and include acetylation, methylation, phosphorylation, ubiquitination, sumoylation, ADP ribosylation, and many others. These PTMs are controlled by different actors, such as histone acetyltransferases (HATs) and histone deacetylases (HDACs), which, respectively, place or remove an acetyl from the tails of histones. Histone methyltransferases (HMTs) and histone demethylases (HDMs) add or remove one or more methyl groups [11].

The hypoacetylation and hypermethylation of histone tails are often associated with chromatin closure and low transcriptional activity, while histone tail hyperacetylation and hypomethylation are usually associated with chromatin opening and the high transcription of genes [12]. The acetyl group neutralizes the positive charge of lysine and causes a lower interaction with the negative charge of DNA phosphates. This results in relaxation of the chromatin [13].

The constant "cross-talk" between the different epigenetic marks positioned in the genome at a given time leads to real complexity in the understanding of epigenetic modifications. This, in turn, has a different impact on the gene expression, integrity, and stability of the genome $[7,14]$.

\subsection{JMJD3 Demethylase}

Demethylase JMJD3, also known as lysine-specific demethylase 6B (KDM6B) belongs to the JmjC-containing protein family, members of which are highly conserved during evolution [15], with activity dependent on $\alpha$-ketoglutarate and oxygen and requiring $\mathrm{Fe}(\mathrm{II})$ as a cofactor [9,16]. The JMJD3 gene is located on chromosome 17p13.1 [17] and has 88\% homology with the gene encoding the ubiquitously repeat transcribed tetratricopeptide repeat on the X chromosome (UTX) [18]. UTX is also capable of removing the di-trimethylation of H3K27 [9,16,18,19].

H3K27me3 is known to be a repressive epigenetic mark deposited thanks to the SET catalytic domain of Zeste Homolog 1 methyltransferase activator (EZH1) and Enhancer of Zeste Homolog 2 (EZH2) when combined with the Polycomb repressive complex 2 (PCR2). It is notably found in facultative heterochromatin [10] and is read by the Polycomb repressive complex 1 (PCR1) which ubiquitinates a histone $\mathrm{H} 2 \mathrm{~A}$ lysine that allows the 
recruitment of factors leading to chromatin compaction and consequently a repression of gene expression [20]. The demethylating activity of JMJD3 at H3K27me2/3 makes it a transcription activating protein [21].

JMJD3 demethylase has been widely reported in embryonic development processes. JMJD3 allows the activation of WNT3 via the demethylation of H3K27me3 at the beginning of endoderm differentiation and activation of Dickkopf-related protein 1 (DKK1) at the end of endoderm differentiation [22]. The inactivation of JMJD3 in mice causes respiratory failure, leading to perinatal lethality. JMJD3's activity is essential for maintenance of the pre-Bötzinger complex because the demethylase controls some key regulatory genes of the complex (Reln, March4, Kirrel3, and Esrrg) [23].

Several studies linked the involvement of JMJD3 in osteogenesis, which indirectly activates the HOX and BMP genes, thereby promoting osteogenic differentiation [24]. In addition, JMJD3 plays a regulatory role in HOX expression during axial structuring in mice [25]. The transcription factor promyelocytic leukaemia zinc finger (PLZF) is essential for the osteogenic differentiation of human mesenchymal stem cells (hMSCs). During the pre-osteoblast differentiation stage, the recruitment of JMJD3 during gene coding for PLZF, coupled to H3K27ac's enrichment of the locus, contributes to PLZF overexpression [26]. JMJD3 is also a key regulator of the cartilage maturation process during enchondral ossification by promoting the expression of Runt-related transcription factor 2 (RUNX2), an essential transcription factor for chondrocyte maturation and by enhancing osteoblast differentiation and, therefore, skeletal ossification [27,28].

JMJD3 appears to have a significant role in hematopoiesis, in association with vita$\min C$, and demethylase appears to be essential in hematopoietic stem cell production in zebrafish and humans. [29]. Also in a zebrafish model, JMJD3 was shown to be important in early myelopoiesis regulation by promoting the expression of Spi1, an essential transcription factor for myelopoiesis in vertebrates [30].

A few studies shed light on the correlation between JMJD3 and immunity: H3K27me3 demethylation by JMJD3 or UTX allows the expression of specific genes responsible for the terminal differentiation of immune T cells. For example, one of these genes, Sphingosine-1Phosphate Receptor 1 (S1PR1) codes for a sphingosine receptor, which is essential to the release of differentiated cells from the thymus and Kruppel Like Factor 2 (KLF22) coding for a transcription factor involved in the late maturation of T cells [31].

In 2007, de Santa et al. demonstrated a link between inflammation and epigenome reprogramming. A strong induction of JMJD3 was observed in mouse macrophages after stimulation by lipopolysaccharides (LPSs), acting during inflammation [32]. In 2012, the same observation was made after the catalytic activity of JMJD3 was inhibited by GSK-J1. JMJD3 induction was directly regulated by the NF-kB transcription factor, an essential factor in gene inflammation induction [33]. More recently, JMJD3 activity inhibition by its chemical inhibitor ethyl 3-((6-(4,5-dihydro- $1 H$-benzo[ $d]$ azepin-3(2H)-yl)-2-(pyridin-2yl)pyrimidin-4-yl)amino)propanoate (GSK-J4) showed a decline in Natural Killer (NK) activities, immune cells that have a pro-inflammatory effect. H3K27 demethylation induced by JMJD3 is important for NK cell function [34].

Neuronally, JMJD3 is involved in the survival of differentiated neurons from the hippocampus and is also important in regulating the maturation of granular cerebellar neurons in mice. This makes the transcription of genes such as Tiam1 and Grin2c able to regulate the Brain-Derived Neurotrophic Factor (BDNF), an important regulator of brain development [35].

JMJD3 demethylase also has a role independent of demethylation. Data show that JMJD3 acts in chromatin remodeling independently of its demethylase activity through interaction with transcription factors such as T-bet, T-box, and the SWI/SNF remodeling complex [36,37]. In addition, JMJD3 has been shown to have a role in cellular reprogramming. JMJD3 inhibits the cell reprogramming mediated by transcription factor Oct4 by targeting PHF20 independently of its demethylase activity. PHF20 is then ubiquitylated via an E3 ligase and is directed to the proteasome to be degraded [38]. 


\subsection{JMJD3 and Cancer}

A number of studies have highlighted the link between JMJD3 and tumor progression. However, its role in oncology is still unclear-is there a balance between oncogenic or tumor suppressor activity in JMJD3?

\subsubsection{Nervous System Cancer \\ Glioblastoma}

The brain is the organ for which JMJD3 has been the most studied. Among different cancers that affect the brain, glioma or glioblastoma are those for which we have collected the most data.

Glioblastoma is the most common and aggressive carcinoma of the central nervous system. In children with pediatric brainstem glioma, a common mutation in the H3F3A gene that codes for a variant of the histone $\mathrm{H} 3.3$ has been observed. This mutation leads to PCR2 sequestration and a decrease in $\mathrm{H} 3 \mathrm{~K} 27 \mathrm{me} 3$, as well as more significant disease progression. Methylation maintenance by inhibiting JMJD3 has been shown to be a therapeutic strategy for glioma treatment $[39,40]$. JMJD3 is overexpressed in glioma tissue relative to healthy tissue. The inhibition of demethylase activity, and hence the maintenance of transcriptional gene repression, resulted in decreased cell proliferation and migration, as well as increased apoptosis [41]. These results were later confirmed after JMJD3 inhibition by Clustered Regularly Interspaced Short Palindromic Repeats Interference (CRISPRi), which still resulted in a decrease in glioma cell proliferation, migration, and invasion, making JMJD3 an oncogene involved in the epithelial-mesenchymal transition (EMT). JMJD3 is also able to increase EMT marker expression, such as the expression of snail homolog 1 (SNAI1) [42], whose overexpression leads to an increase of $\mathrm{N}$-cadherins and fibronectin proteins by regulating the C-X-C motif chemokine 12 (CXCL12) at the transcriptional and translational levels [43].

By contrast, some studies highlighted JMJD3 as a tumor suppressor gene in glioblastoma. Most of these genes, including the p53 transcription factor, are known to have a role in senescence and DNA repair, inhibit angiogenesis, and thus, act as a tumor suppressor actor [44]. JMJD3's methylation state has been demonstrated to be essential for its function [45]. A study showed that JMJD3 is able to regulate p53 independently of chromatin modification but directly via interaction with p53. This leads to glioblastoma stem cell (GSC) differentiation, which suppresses GSC proliferation [46]. Interestingly, JMJD3 is a direct target of Signal transducer and activator of transcription 3 (STAT3). STAT3 binds to the JMJD3 promotor, resulting in the promotor's repression. The overexpression of JMJD3, after STAT3 inhibition, indicates a decrease in neurosphere formation, cell proliferation, and, therefore, tumorigenicity. JMJD3 regulation by STAT3 was found in tumor samples from different patients [47]. These results together with those of Ene et al. show the importance of JMJD3's role in GSCs differentiation and GSC proliferation [46,47]. Receptor tyrosine kinase (RTK) overexpression, such as that due to platelet-derived growth factor receptor A (PDGFR $\alpha$ ), plays an important role in the regulation of cell growth and survival. PDGFR $\alpha$ is amplified to $5-10 \%$ in glioblastoma [48]. By targeting PDGFR $\alpha$ with an aptamer of its ligand, the PDR3 has been shown to decrease STAT3 expression and increase JMJD3 expression. Aptamer treatment also resulted in an increase in P53 in response to increased JMJD3 expression [49]. This result places JMJD3 in a central position between STAT3 and p53 in limiting tumor progression.

\section{Medulloblastoma}

Among brain cancers, medulloblastoma (MB) is a cancer that mostly develops in children ( $9.2 \%$ of brain tumors) between 0 and 14 years of age, with a peak of incidence during the first decade [50]. JMJD3's role is controversial in this type of pathology. It was first demonstrated in 2014 in vitro and in vivo on mice that JMJD3 acts in favor of carcinogenesis by modulating bivalent chromatin domain expression. These domains contain the repressive mark H3K27me3 and the active mark H3K4me3. Gene expression in these regions remains inactive but awaits activation. In association with Shh signaling, 
JMJD3 demethylates H3, activating Shh target genes, such as GliA. These genes play a predominant role in the proliferation of cerebellum granule neuron precursors (CGNPs) in the early postnatal period. Moreover, the Shh MB subtype features low H3K27me3 accumulation, suggesting that JMJD3 is more active in tumors compared to normal cerebellar tissues and that JMJD3 demethylase activity inhibition by shRNA in Shh MB subtypes leads to a decrease in CGNP proliferation and thus a decrease in growth MB [51].

Conversely, analyses were performed on tumor and healthy human samples in 2017. It was demonstrated via immunohistochemistry that the expression of topoisomerase II $\beta$ (topoII $\beta$ ), a protein essential for DNA repair, was inversely correlated with the repressive mark H3K27me3 in MB tumors with low topoIIB expression. JMJD3 expression was higher in normal tissues than in MB tissues, making JMJD3 a protein involved in topoIIB expression maintenance and helping to limit tumor progression [52].

\section{Neuroblastoma}

Neuroblastoma are cancers that develop from the neural crests responsible for the sympathetic nervous system and adrenal gland formation and account for $8-10 \%$ of all tumors in children. MYCN gene amplification is highly relevant to the loss of differentiation potential and the poor prognosis associated with this disease [53]. JMJD3 inhibition in neuroblastoma has been shown to be favorable to carcinogenesis reduction by modulating the expression of key genes involved in the formation of neuroblastoma and notably by reducing MYCN proto-oncogene expression and overexpressing the p53 and the p53 upregulated modulator of apoptosis (PUMA) factors involved in apoptosis. GSK-J4 inhibitor treatment has been shown to be effective in combination with retinoic acids, leading to a more effective reduction in cell viability, as well as the induction of cell differentiation and reticulo-endoplasmic stress, which leads to cell death [54].

\subsubsection{Prostate Cancer}

Presently, 1,276,106 men worldwide have been diagnosed with prostate cancer (PC), and 358,989 deaths are estimated. After lung and colorectal cancer, prostate cancer is the third most common cancer among men [1].

Increasingly more studies are highlighting the implications of epigenetic alterations in prostate tumor progression. Several studies highlighted EZH2 overexpression in PC [55,56]. EZH2 methyltransferase inhibition results in decreased proliferation, suggesting that decreased $\mathrm{H} 3$ methylation has a protective effect on the cancer development. Therefore, JMJD3's involvement as an $\mathrm{H} 3$ demethylase appears to be essential to limit tumor progression [55]. On the other hand, it seems surprising that EZH2 and JMJD3 are concomitantly overexpressed during PC development [55,57]. A study by Xiang and colleagues discussed this phenomenon: $\mathrm{PC}$ is a heterogeneous cancer [9] with different degrees of aggressiveness (Gleason score (GS)). The two proteins EZH2 and JMJD3 may act differently depending on the type of PC. Moreover, several studies have revealed this phenomenon, according to which there is a differential overexpression of EZH2 and JMJD3 depending on the aggressiveness of the disease [56,58,59]. A global genome-wide analysis of H3K27me3 was performed on prostate biopsies representing three clinical groups (healthy, GS $\leq 7$, and GS > 7), and a strong representation of H3K27me3 was found in tumor tissue compared to healthy tissue, with a positive correlation according to the GS [60]. Another study showed the impact of H3K27me3 on the regulation of the Retinoic acid receptor $\beta 2$ (RAR $\beta 2$ ), estrogen receptor $(E r \alpha)$, progesterone receptor $(P G R)$, and Repulsive Guidance Molecule A $(R G M A)$ genes and also correlated H3K27me3 with the level of tumor aggressivity [57]. These genes are involved in PC development. The coverage of these previous genes by JMJD3 and EZH2 is greater in PC cell lines than in healthy cells with larger JMJD3 coverage at the these gene promotors [56].

PC is a hormone-dependent cancer and is particularly androgen-dependent. Thus, understanding the link between androgen receptor (AR) and PC development is essential to better treat this disease. Like many genes, AR expression is modulated by epigenetic 
mechanisms. AR is overexpressed in PC, as well as in $30 \%$ of castration-resistant PC (CRPC) compared to untreated PC [61]. A number of studies have suggested a possible link between JMJD3, H3K27me3, and the AR metabolic pathway [56,57,61-64]. JMJD3's transcriptional level is increased in LNCaP AR+ tumor cell lines compared to PC-3 ARtumor cell lines [56]. This comment also applies to JMJD3's enrichment on four candidate genes $(\mathrm{O}-$ methylguanine-DNA methyltransferase $(M G M T)$, transformer 2 alpha homolog (TRA2A), 2 small nuclear RNA auxiliary factor 1 (U2AF1), and ribosomal protein 56 kinase A2 (RPS6KA2)), identified as signature genes in PC [59]. After GSK-J4 inhibitory treatment of JMJD3, AR - tumor cells did not show an increase in JMJD3 on the promotor of candidate genes, while AR+ tumor cells did show an increase [62]. This observation was echoed at the transcriptional level on the same genes after inhibitor treatment [56]. The relevance of androgens in PC and epigenetics was reported by Sun et al.: The repressive cluster $\mathrm{miR} 99 \mathrm{a} /$ let7c/125-b that contributes to a decrease in cell growth is regulated by androgens and by the couple, EZH2/JMJD3. JMJD3 expression induces an increase in miRNA cluster expression giving it a tumor suppressor role [65].

While Varambally et al.'s work showed that EZH2 inhibition resulted in reduced cell proliferation [55], a study conducted on AR-WT and AR- $\triangle$ LBD tumor cells (CRPC cell lines) showed that JMJD3 inhibition by GSK-J4 also resulted in reducing PC cell proliferation [61]. This confirms the complexity of the epigenetic mechanisms and the need to balance understanding of JMJD3/EZH2 in PC.

One study proposed a model in which JMJD3 would have an oncogenic effect. JMJD3's inhibition by Triptolide, extracted from a medicinal herb, would have an anti-tumor effect on PC tumor cells. This compound would induce an increase in H3K27me3 after JMJD3 inhibition and an increase in H3K9me3 by positively regulating the SUV39H1-HP1 $\alpha$ complex, which is involved in heterochromatin formation. The increase in these two repressive marks would result in gene transcription suppression, as well as an increase in senescence [66].

\subsubsection{Blood Cancer}

There are a wide variety of blood disorders, including T-cell acute lymphoblastic leukemia (T-ALL), acute myeloid leukemia (AML), Hodgkin's lymphoma (HL), and diffuse large B-cell lymphoma (DLBCL), also known as Non-Hodgkin's lymphoma. These various disorders are caused by the deregulation of a number of signaling pathways in which JMJD3, in some cases, also appears to be involved.

\section{T-ALL}

This pathology affects both children and adults and is due to a deregulation of thymocyte $\mathrm{T}$ growth and maturation, wherein Notch receptor 1 (NOTCH1) is overexpressed in $60 \%$ of cases. NOTCH1 is implicated in the oncogenic pathways. In 2014, JMJD3 was identified as a central player in oncogene activation mediated by NOTCH1. JMJD3 was found to be overexpressed and colocalized with NOTCH1 in T-ALL cells. Ubiquitin-specific peptidase 7 (USP7) stabilizes the complex NOTCH1/JMJD3 through deubiquitination. The NOTCH1 oncogenic targets are controlled by this mechanism in controlling the demethylation of target genes through JMJD3 activity. It was demonstrated that concomitant USP7 and JMJD3 inhibition lead to a reduction of tumor growth in vivo. [67]. JMJD3 was found at the promotor site of NOTCH1 targets that have oncogenic functions: HES1, HEY1, NRARP [68], c-myc, and Notch receptor 3 (NOTCH3) [69]. This allows T-ALL cell initiation and maintenance by controlling the methylation of oncogenic targets [68]. These studies suggest that JMJD3 is an interesting therapeutic target to reduce T-ALL progression. Other researchers have examined JMJD3's functions in hematopoietic stem cells (HSCs) that are not related to chromatin modification. As in T-ALL cells, JMJD3 is overexpressed in HSCs, and JMJD3 loss upregulates the transcription factor AP-1 and increases the downstream expression of Jun and Fos, resulting in the inability of HSCs to self-renew after stress. In a T-ALL model transduced with a retrovirus expressing the NOTCH1 intra-cellular domain, 
the authors showed that JMJD3 loss did not produce greater survival, unlike the AML model. The initiation and maintenance of T-ALL and AML by JMJD3 would depend on the cell subtype and developmental context. JMJD3 could be an interesting target if its inhibition does not affect normal HSCs but only those implicated in leukemia [70].

\section{AML}

On the other hand, JMJD3, when induced by all-trans retinoid acid (ATRA) signaling, is also known to have an oncorepressive role as it acts on targets such as C/EBP $\beta$ and RIPK3 (a key suppressor of AML malignancy) that allow the myeloid differentiation, cell cycle arrest, and cell death of AML cells [71]. In the context of differentiation therapy, JMJD3 has also been shown to allow malignant cells to differentiate into treatable differentiated cells. In AML, Aurora kinase (AURK) A represses JMJD3 expression, thus favoring leukemogenesis and justifying the predominant role of JMJD3 in the repression of AML progression [72].

In contrast, other studies demonstrated the oncogenic role of JMJD3 in AML development [73-75]. JMJD3 overexpression in AML cells is associated with a poor prognosis, and JMJD3 inhibition facilitates an increase in H3K27 methylation associated with a decrease in proliferation and HOX expression in vitro, as well as a decrease in disease progression in vivo. [75]. Illiano et al. demonstrated a link between the cAMP response elementbinding protein (CREB), which plays a critical role in leukemogenesis, and JMJD3 by using GSK-J4 treatment on AML cell lines. The use of GSK-J4 permits the downregulation of CREB. The latter protein is phosphorylated on Ser-133 by a protein kinase A (PKA) before being directed to the proteasome [73]. Moreover, it seems that the association of GSK-J4 with a natural cAMP raising compound (forskolin) potentiates the anti-proliferative effects of GSK-J4 via PKA in some AML cells (U937 cells), leading to B-cell lymphoma 2 protein (BCL2) downregulation and caspase 3 activation [74].

\section{Lymphoma}

Whether in HL [76] or DLBCL [77,78], JMJD3 is over-expressed in germinal center B (GC-B) cells. JMJD3 is modulated by viruses such as the Epstein-Barr virus (EBV), which is involved in the development of GC-B and the development of HL. EBV and the latent oncoprotein membrane protein-1 (LMP1), modified in $50 \%$ of HLs by EBV, induce strong regulation of JMJD3 in primary B cells. The NOTCH homolog $2 \mathrm{~N}$-terminal-like (NOTCH2NL) and CD58 genes have been identified as JMJD3 targets in GC-B and are overexpressed in HL cells. After JMJD3 inhibition by interfering RNA, a reduction of H3K27me3 is observed on target genes, which provides sufficient evidence that JMJD3 is involved in the development of HL via LMP1 in GC-B [76].

In DLBCL, JMJD3 overexpression in GC-B is associated with a poor prognosis. Demethylation, moreover, plays a role in disease development. JMJD3 affects the B-cell receptor (BCR) and the downstream B-cell lymphoma 6 protein (BCL6). These proteins are involved in B-cell survival, and the use of the JMJD3 inhibitor significantly sensitizes B cells to chemotherapy treatments compared to the use of treatments alone [77]. In both subtypes of DLBCL, which are the ABC or GCB subtypes, overexpressed JMJD3 acts on the regulatory factor 4 interferon (IRF4), which plays a role in hematopoietic cell differentiation. On the other hand, two distinct mechanisms have been put forward depending on DLBCL type: The ABC subtype seems to use a pathway linking JMJD3-IRF4-NF-kB to induce cell survival, while for the GCB subtype, survival is mediated by the Bcl-2 survival gene, which is sensitive to JMJD3 demethylase activity [78]. There also appears to exist a connection between JMJD3 demethylase and cyclin-dependent kinase 9 (CDK9), which is abnormally expressed in DLBCL cells. CDK9 inhibitors utilization affects JMJD3 and H3K27 methylation leading to a weakening of the expression of anti-apoptotic myeloid cell leukemia 1 (MCL1) and X-linked inhibitor of apoptosis (XIAP) proteins [79].

However, in anaplastic large cell lymphomas (ALCLs), an oncogenic mutation, such as in the $\mathrm{N}$-terminal portion of nucleophosmin and in the intracellular domain of anaplastic lymphoma kinase (NPM-ALK), in cells may lead to a weak expression of the p16INK4a/ Rb 
tumor suppressive pathway. This pathway activates oncogene-induced senescence (OIS), which limits tumor development. JMJD3 is found to be a partial contributor to the activation of p16INK4a/Rb in an NPM-ALK context and could be a novel agent to contribute to the upregulation of the $\mathrm{p} 16 \mathrm{INK} 4 \mathrm{a} / \mathrm{Rb}$ pathway [80].

\subsubsection{Colorectal Cancer}

Colorectal cancer (CRC) is the second most deadly cancer in the world [1], but relatively few investigations address the contribution of JMJD3 to the development of CRC.

Once again, JMJD3 presents itself as a double actor. It is under expressed in CRC on clinical samples [81] and acts as a tumor suppressor when activated by the active metabolite of vitamin D: $1,25(\mathrm{OH})_{2} \mathrm{D}_{3}$. Although the mechanism remains unclear, JMJD3's presence limits the expression of key participants implied in EMT (SNAI1, Zinc finger E-box-binding homeobox 1 (ZEB1)) and facilitates chromatin access to the genes involved in cell adhesion and the $1,25(\mathrm{OH})_{2} \mathrm{D}_{3}$ target genes (CYP24A, CDHA1/E-cadherin, and CST5/cystatin D), all of which have a role in restraining tumor progression [82,83]. In Tokugunaga et al., the loss of the JMJD3 was considered a marker of poor prognosis in CRC and promoted cell proliferation, suppression of apoptosis, and reduction in the expression of the p15INK4b tumor suppressor [81]. JMJD3 also regulates tumor immunity in CRC by enabling the transcription of the Th-1 type chemokine (CXCL9 and CXCL10), and treating the primary cells of CRC with GSK-J4 leads to a reduction in the chemokine level. These chemokines have been shown to be positively correlated with CRC patients' survival [84].

On the other hand, JMJD3 plays a role in the histone promotor demethylation of the epithelial cell adhesion molecule (EpCAM) gene playing a role in the proliferative process in some of cancers and which is overexpressed in CRCs [85]. In addition, the aberrant activation of NOTCH1 in CRC, specifically serrated neoplasia pathway, leads to an increase in Ephrin type-B receptor 4 (EPHB4), which promotes tumor growth and cell migration. It turns out that the intracellular NOTCH domain accompanies JMJD3 from the cytosolic compartment to the nuclear one to modify EPHB4 chromatin architecture in CRC [86]. These latest data position JMJD3 as a CRC oncoprotein.

\subsubsection{Breast Cancer}

Breast cancer $(\mathrm{BC})$ is the leading cause of death in women worldwide [1]. There are different subtypes of this cancer depending on the expression of a number of receptors [87]. On the other hand, hormone-dependent BCs may become resistant to hormonotherapy, hence the interest in finding new therapeutic strategies. Among those strategies, epigenetics is increasingly revealing itself as an interesting area of research in the discovery of new targets for anti-cancer treatments.

Svotelis et al. showed that after stimulation of Er $\alpha$ by estrogens, JMJD3 is co-recruited at the $\operatorname{Er} \alpha$ binding regions on the promotor of the B-cell lymphoma 2 (BCL2) anti-apoptotic gene to induce its expression. The link between the modification of BCL2's chromatin architecture and its constitutive activation in estrogen-resistant cancer cells has been demonstrated, identifying JMJD3 and methyltransferase EZH2 as interesting therapeutic targets. Indeed, estrogen-resistant cancer cells overexpress HER2, which results in the constitutive activation of BCL2 by inactivating EZH2 through the AKT pathway. In this case, the involvement of JMJD3 is no longer needed, which highlights the existence of non-genomic pathways in the regulation of the BCL2 gene by EZH2, whereas JMJD3 is able to positively regulate $B C L 2$ expression in a genomic way in non-resistant breast cancer cell lines [88]. JMJD3 could be targeted in nonresistant cancer cells, and EZH2 in both nonresistant cancer cells and estrogen-resistant cancer cells, to limit BCL2 activation.

It is clear that JMJD3 has a role on cancer stem cell (CSC) pluripotency. In BC, JMJD3 has an inhibitory effect on Oct4 (stemness marker) via the degradation of PHF20 in triplenegative and luminal BC cell models [89]. In both luminal and triple-negative models, JMJD3 acts in disfavor of stemness characteristics. The same finding was reported by Zhao et al. on fibroblasts [38]. However, a further study highlighted the favorable effect 
of inhibiting JMJD3 in limiting tumor progression in vitro and in vivo with a decrease in cell proliferation and pluripotency markers (Nanog, Sox2, and Oct4) and in tumor size and weight after GSK-J4 treatment [90]. In addition, as previously seen in CRC [82,83], Xun et al. confirmed that JMJD3 is activated by vitamin D analogues such as paricalcitol (vitamin D receptor agonist), also resulting in decreased stem-cell-like properties [89]. Controversially, JMJD3 is involved in promoting the mesenchymal characteristics induced by TGF- $\beta$ and activating SNAI1 in BC [91]. An additional study showed that the microenvironment plays a role in the activity of JMJD3 and, particularly, hypoxia within tumors through a reduction in the activity of demethylase and, consequently, a greater presence of the H3K27me3 marker at the epigenome [92]. While Wei et al. demonstrated that a loss of H3K27 trimethylation is associated with a poor predictor in BC [93], another team highlighted the link between hypoxia, JMJD3, and the development of stem cell capacity by regulating the methylation state of DICER. The lack of oxygen leads to a reduction of JMJD3 oxygen-dependent demethylase activity that reduces DICER expression because of its over-methylated state. DICER controls miRNA production and DICER repression, leading to a repression of the miR-200 family that activates EMT [92,94]. In this context, JMJD3 activity seems to be important to counter the development of stem cell capacity and EMT, thus reducing metastasis.

\subsubsection{Lung Cancer}

JMJD3's function in lung cancer is controversial. In the cell model of adenocarcinomic human alveolar basal epithelial cells (A549 cell line), JMJD3 contributes to the proliferation of A549 by affecting the cell cycle (decreasing p21 mRNA production), but has no effect on cell migration [95]. Conversely, a recent study showed its effects on EMT activation and its favorable influence on cell migration in a non-small cell lung cancer (NSCLC) model [96]. The same study also demonstrated an elevation in the expression of JMJD3 in the tumor tissue and showed a positive correlation with cancer progression to lymph node metastasis. These results are consistent with those found in primary sarcomatoid carcinoma of the lung, which is a type of pulmonary sarcomatoid carcinoma where JMJD3 is inversely correlated with patient survival [97]. This is of interest as a study performed on human serum samples from blood (healthy or NSCLC-affected) showed a decrease in the JMJD3 mRNA expression of serum NSCLC positively correlated with disease severity (N1 and N2 metastasis nodes) [98]. This differential expression of JMJD3 between serum and tumor tissue could potentially establish JMJD3 as a diagnostic tool and biomarker for NSCLC.

\subsubsection{Other Types of Cancer}

The table below summarizes and describes how JMJD3 is regulated in previously described cancers and liver, ovarian, and gastric cancer and what the consequences are in terms of its role in favor of, or against, tumor progression (Table 1).

Table 1. Jumonji domain-containing protein 3 demethylase regulation in liver, ovarian, and gastric cancers $^{\mathrm{a}}$.

\begin{tabular}{|c|c|c|c|c|}
\hline Types of Cancer & Up/Down Regulation & How? & $\begin{array}{l}\text { Oncogene/ } \\
\text { Tumor } \\
\text { Suppressor }\end{array}$ & References \\
\hline \multirow{3}{*}{ Liver } & Upregulated & $\begin{array}{c}\text { + EMT } \\
+ \text { Migration } \\
+ \text { Invasion }\end{array}$ & Oncogene & [99] \\
\hline & & $\begin{array}{c}\text { via slug demethylation } \\
\text { - EMT }\end{array}$ & & \\
\hline & $\begin{array}{l}\text { Downregulated by miR-941 in } \\
\text { hepato carcinoma cell lines }\end{array}$ & $\begin{array}{c}\text { - Invasion } \\
\text { - Migration } \\
\text { - Proliferation }\end{array}$ & $\begin{array}{l}\text { Tumor } \\
\text { Suppressor }\end{array}$ & [100] \\
\hline
\end{tabular}


Table 1. Cont.

\begin{tabular}{|c|c|c|c|c|}
\hline Types of Cancer & Up/Down Regulation & How? & $\begin{array}{l}\text { Oncogene/ } \\
\text { Tumor } \\
\text { Suppressor }\end{array}$ & References \\
\hline \multirow[t]{2}{*}{ Ovarian } & Upregulated & $\begin{array}{c}\text { + Cell death } \\
\text { + Self-renewal } \\
\text { + Tumor initiation } \\
\text { + EMT } \\
\text { + Migration } \\
\text { + Invasion } \\
\text { + Proliferation } \\
\text { + Metastatic Capacities } \\
\text { via TGF- } \beta 1 \text { expression }\end{array}$ & Oncogene & [101] \\
\hline & $\begin{array}{l}\text { Upregulated in drug resistant } \\
\text { ovarian cancer cells, positively } \\
\text { correlated with HER2 } \\
\text { expression }\end{array}$ & + HER2 expression & Oncogene & [103] \\
\hline \multirow[b]{2}{*}{ Gastric } & Upregulated & $\begin{array}{l}\quad \text { - Survival } \\
+ \text { Proliferation }\end{array}$ & Oncogene & [104] \\
\hline & - & $\begin{array}{l}+\mathrm{p} 15 / \mathrm{p} 16 \text { when associated } \\
\text { with Long noncoding RNAs } \\
\text { (ARHGAP27P1) }\end{array}$ & $\begin{array}{l}\text { Tumor } \\
\text { suppressor }\end{array}$ & [105] \\
\hline Glioblastoma & Upregulated & $\begin{array}{c}\text { + Tumor growth } \\
\text { + Proliferation } \\
\text { - Apoptosis } \\
\text { + Migration } \\
\text { + Invasion } \\
\text { + EMT (SNAI1 and fibronectin } \\
\text { and N-cadherins by regulating } \\
\text { CXCL12) } \\
\text { + P53 } \\
\text { - Neurosphere formation } \\
\text { - Proliferation }\end{array}$ & $\begin{array}{l}\text { Tumor } \\
\text { suppressor }\end{array}$ & {$[46,47,49]$} \\
\hline \multirow{2}{*}{ Medulloblastoma } & Upregulated & $\begin{array}{l}+ \text { Proliferation (+ shh } \\
\text { signaling) }\end{array}$ & Oncogene & [51] \\
\hline & Downregulated & $\begin{array}{c}\text { + DNA repair } \\
(+ \text { topoII } \beta)\end{array}$ & $\begin{array}{l}\text { Tumor } \\
\text { suppressor }\end{array}$ & [52] \\
\hline Neuroblastoma & - & $\begin{array}{c}\text { + Differentiation } \\
(-M Y C N) \\
+ \text { Apoptosis (p53, PUMA) } \\
+ \text { Cell death } \\
\text { (+ reticulo-endoplasmic stress) }\end{array}$ & $\begin{array}{l}\text { Tumor } \\
\text { suppressor }\end{array}$ & {$[53,54]$} \\
\hline \multirow{2}{*}{ Prostate cancer } & \multirow{2}{*}{$\begin{array}{l}\text { Upregulated } \\
\text { (Differential expression } \\
\text { according to AR status and } \\
\text { aggressiveness) }\end{array}$} & $\begin{array}{l}\text { + Proliferation } \\
\text { + Senescence }\end{array}$ & Oncogene & {$[61,66]$} \\
\hline & & $\begin{array}{c}- \text { Proliferation } \\
+ \text { DNA repair }(+M G M T)\end{array}$ & $\begin{array}{l}\text { Tumor } \\
\text { suppressor }\end{array}$ & $\begin{array}{l}{[55,57,59,62,} \\
65]\end{array}$ \\
\hline T-ALL & Upregulated & $\begin{array}{l}\text { + NOTCH1 target genes } \\
+ \text { Tumor growth } \\
+ \text { AP-1 }\end{array}$ & Oncogene & {$[67-70]$} \\
\hline \multirow[b]{2}{*}{ AML } & - & $\begin{array}{l}\text { + Differentiation } \\
\text { + Cell cycle arrest } \\
\text { + Cell death } \\
\text { + C/EBP } \beta \text { and RIPK3) }\end{array}$ & $\begin{array}{l}\text { Tumor } \\
\text { suppressor }\end{array}$ & {$[71,72]$} \\
\hline & Upregulated & $\begin{array}{c}\text { + Proliferation } \\
+ \text { Disease progression } \\
+ \text { HOX } \\
\text { cAMP/PKA }\end{array}$ & Oncogene & [73-75] \\
\hline $\mathrm{HV}$ & Upregulated & $\begin{array}{c}\text { JMJD3 activated by LMP1 } \\
+ \text { NOTCH2NL }\end{array}$ & Oncogene & [76] \\
\hline DLBCL & Upregulated & $\begin{array}{l}\text { + Survival (BCR, BCL6, } \\
\text { IRF4-NF-kB, BCL2)- } \\
\text { Apoptosis (XIAP, MCL1) }\end{array}$ & Oncogene & [77-79] \\
\hline \multirow[b]{2}{*}{ ALCL } & - & + p16INK4a/Rb pathway & $\begin{array}{l}\text { Tumor } \\
\text { suppressor }\end{array}$ & [80] \\
\hline & - & $\begin{array}{c}\text { + Proliferation }(+ \text { EpCam) } \\
\text { + Tumor growth } \\
\text { +Migration } \\
\text { (NOTCH1/JMJD3 } \rightarrow+\text { ) }\end{array}$ & Oncogene & {$[85,86]$} \\
\hline
\end{tabular}


Table 1. Cont.

\begin{tabular}{|c|c|c|c|c|}
\hline Types of Cancer & Up/Down Regulation & How? & $\begin{array}{l}\text { Oncogene/ } \\
\text { Tumor } \\
\text { Suppressor }\end{array}$ & References \\
\hline $\begin{array}{l}\text { Colorectal } \\
\text { cancer }\end{array}$ & Downregulated & $\begin{array}{l}\text { JMJD3 activated by Vitamin D } \\
\text { active metabolite } \\
\text { - EMT (-SNAI1, - ZEB1, } \\
\text { + cell adhesion genes) } \\
\quad \text { - Proliferation } \\
\quad \text { + Apoptosis } \\
\quad \text { + P15INK4B } \\
\text { + Survival (+CXCL9, CXCL10) }\end{array}$ & $\begin{array}{c}\text { Tumor } \\
\text { suppressor }\end{array}$ & [81-84] \\
\hline Breast cancer & - & $\begin{array}{l}\text { - Survival (+ BCL2) } \\
\text { + Proliferation } \\
\text { + Pluripotency } \\
\text { (Nanog, Sox, Oct4) } \\
\text { + Tumor growth } \\
\text { + EMT (JMJD3 activated by } \\
\text { TGF } \beta \rightarrow+\text { SNAI1) } \\
\text { - Pluripotency }(- \text { Oct4)- } \\
\text { Stem-like properties } \\
\text { - EMT (+DICER } \rightarrow \\
\text { - miR-200) }\end{array}$ & $\begin{array}{c}\text { Tumor } \\
\text { suppressor }\end{array}$ & $\begin{array}{c}{[88,90,91} \\
93]\end{array}$ \\
\hline Lung cancer & Upregulated & $\begin{array}{l}\text { + Cell cycle }(- \text { p21) } \\
+ \text { EMT (Migration) } \\
+ \text { Metastasis } \\
\text { - Survival }\end{array}$ & Oncogene & [95-98] \\
\hline \multicolumn{5}{|c|}{$\begin{array}{l}\text { a EMT: Epithelial-mesenchymal transition; CXCL12: C-X-C motif chemokine 12; topoII } \beta \text { : Topoisomerase ii } \beta \text {; } \\
\text { SNAI1: Snail homolog 1; ZEB1: Zinc finger E-box-binding homeobox 1; Topoisomerase ii } \beta \text {; MGMT: O- } \\
\text { methylguanine-DNA methyltransferase; NOTCH1: Notch receptor 1; CREB: cAMP response element-binding } \\
\text { protein; PKA: Protein kinase A; LMP1: Latent membrane protein-1; NOTCH2NL: Notch homolog } 2 \text { N-terminal- } \\
\text { like; BCR: B-cell receptor; BCL6: B-cell lymphoma } 6 \text { protein; IRF4: Regulatory factor } 4 \text { interferon; BCL2: B-cell } \\
\text { lymphoma } 2 \text { protein; XIAP: X-linked inhibitor of apoptosis; PUMA: p53 upregulated modulator of apoptosis; } \\
\text { MCL1: Myeloid cell leukemia 1; EpCam: Epithelial cell adhesion molecule; JMJD3: Jumonji Domain-Containing } \\
\text { Protein } 3 \text { demethylase. }\end{array}$} \\
\hline
\end{tabular}

\subsection{Epi-Drugs of JMJD3}

As previously highlighted in this review, epi-drugs are increasingly evolving towards new therapeutic strategies against cancer to regulate cancer progression. In the table below (Table 2.), we listed a few molecules likely to target JMJD3 in cancer and other pathologies.

GSK-J4 is the most studied molecule related to JMJD3 targeting and is an ester derivative of the GSK-J1 molecule. GSK-J4 is able to penetrate cells more easily and is hydrolyzed to GSK-J1, which binds to the active site of JMJD3 competitively with $\alpha$-ketoglutarate [33].

A team recently developed pan-histone demethylase inhibitors based on the chemical characteristics of tranylcypromine (a known inhibitor of Lysine-specific demethylase 1 (LSD1) belonging to the superfamily of the flavin adenine dinucleotide (FAD)-dependent amine oxidases), with the scaffolds 2,2'-bipyridine or 5-carboxy-8HQ, two competitive groupings of $\alpha$-ketoglutarate. However, these compounds cannot be described as specific for JMJD3 since they simultaneously inhibit LSD1 and enzymes with a jumonji catalytic domain [110]. In addition, seven compounds derived from quinoline-5,8-dicarboxylic acid have been shown to exert strong inhibition on JMJD3 by binding to its active JMJD3 site [111]. Very recently, Giordono et al. also demonstrated the inhibitory effect of a molecule derived from 2-Benzoxazol-2-yl-phenol. One of these compounds (compound 8), moreover, showed cell cycle arrest on melanoma cancer cells [112]. Further, flavonol analogs (myricetin) were modeled, and eight of them appeared to have a strong affinity for the active site of JMJD3 compared to the binding of GSK-J1. On the other hand, these molecules have not been tested in vitro or in vivo [113]. Finally, Zhang et al. identified two new inhibitors (salvianic acid A and puerarin 6"-O-xyloside) using a capillary electrophoresis technique [114]. However, further studies at the cellular level should be done to validate the inhibitory effect of these molecules on JMJD3 (Table 2). 
Table 2. Mechanisms of jumonji Domain-Containing Protein 3 demethylase (JMJD3) epi-drugs.

\begin{tabular}{|c|c|c|}
\hline Epi-Drugs & Mechanisms & References \\
\hline GSK-J4 & $\begin{array}{c}\text { Hydrolyzed to GSK-J1 } \\
\text { Competitive fixation }\end{array}$ & {$[33,34,39,54,67-69,74,75,90,101,104,106-109]$} \\
\hline Pan-histone demethylase inhibitor & $\begin{array}{l}\text { Covalent binding of tranylcypromine fragments and reversible } \\
\text { binding of jumonji domain demethylase inhibitor scaffolds. } \\
\text { Competitive fixation }\end{array}$ & [110] \\
\hline Quinoline-5,8-dicarboxylic Acid Derivative & $\begin{array}{c}\text { Fragmentary approach to quinoline- } 5,8 \text { dicarboxylic acid } \\
\text { Competitive fixation }\end{array}$ & [111] \\
\hline $\begin{array}{l}\text { 2-Benzoxazol-2-yl-phenol Scaffold } \\
\text { (Compound 8) }\end{array}$ & $\begin{array}{l}\text { Fragmentary approach to 2-Benzoxazol-2-yl-phenol } \\
\text { Competitive fixation }\end{array}$ & [112] \\
\hline $\begin{array}{c}\text { Flavonol analogues } \\
\text { (myricetin) }\end{array}$ & Competitive fixation & [113] \\
\hline Salvianic acid A and puerarin 6"-O-xyloside & Identified by capillary electrophoresis & [114] \\
\hline
\end{tabular}

To conclude, there is no doubt that JMJD3 is involved in carcinogenesis. We note that demethylase frequently acts on deregulated pathways in cancers (EMT, cell cycle, and P53). On the other hand, it is difficult to categorize JMJD3 as a tumor suppressor or oncoprotein. We highlighted in this scientific review the heterogeneous tissue-dependent demethylase activity of JMJD3. Within the same organ, the aggressiveness of the disease seems to influence the role of JMJD3. It is well known that epigenetic modifications are complex and that there is permanent context-dependent crosstalk between different epigenetic marks. It would be interesting to better understand this epigenetic dialogue in cancers to identify more precisely the role of JMJD3 in cancers. In addition, molecules (Table 2) capable of modifying JMJD3 activity have been developed. Unfortunately, apart from GSK-J4 and GSK-J1, these molecules are still rarely or never used experimentally, but they could become future epidrugs for clinical trials, treatments, and therapies for cancer patients.

Author Contributions: Conceptualization, A.S., F.Z.H.K., M.I., and D.B.-G.; validation, D.B.-G., L.G., Y.-J.B., and F.P.-L.; resources were collected by A.S.; writing-original draft preparation, A.S.; writing-review and editing, A.S., F.Z.H.K., M.I., and D.B.-G.; supervision, D.B.-G., L.G., Y.-J.B., and F.P.-L. All authors have read and agreed to the published version of the manuscript.

Funding: This research received no external funding.

Institutional Review Board Statement: Not applicable.

Informed Consent Statement: Not applicable.

Acknowledgments: This work was supported by the French Ligue Régionale Contre Le CancerComité du Puy-de-Dôme-and the ARTP (Association pour la Recherche sur les tumeurs de la Prostate).

Conflicts of Interest: The authors declare no conflict of interest.

\section{Abbreviations}

AML Acute myeloid leukaemia

AR Androgen receptor

ATRA All-trans retinoid acid

AURK Aurora kinase

BC Breast cancer

BCL2 B-cell lymphoma 2 protein

BCL6 B-cell lymphoma 6 protein

BCR B-cell receptor

BDNF Brain-derived neurotrophic factor

CDK9 Cyclin-dependent kinase 9

CREB cAMP response element-binding protein

CRC Colorectal cancer 


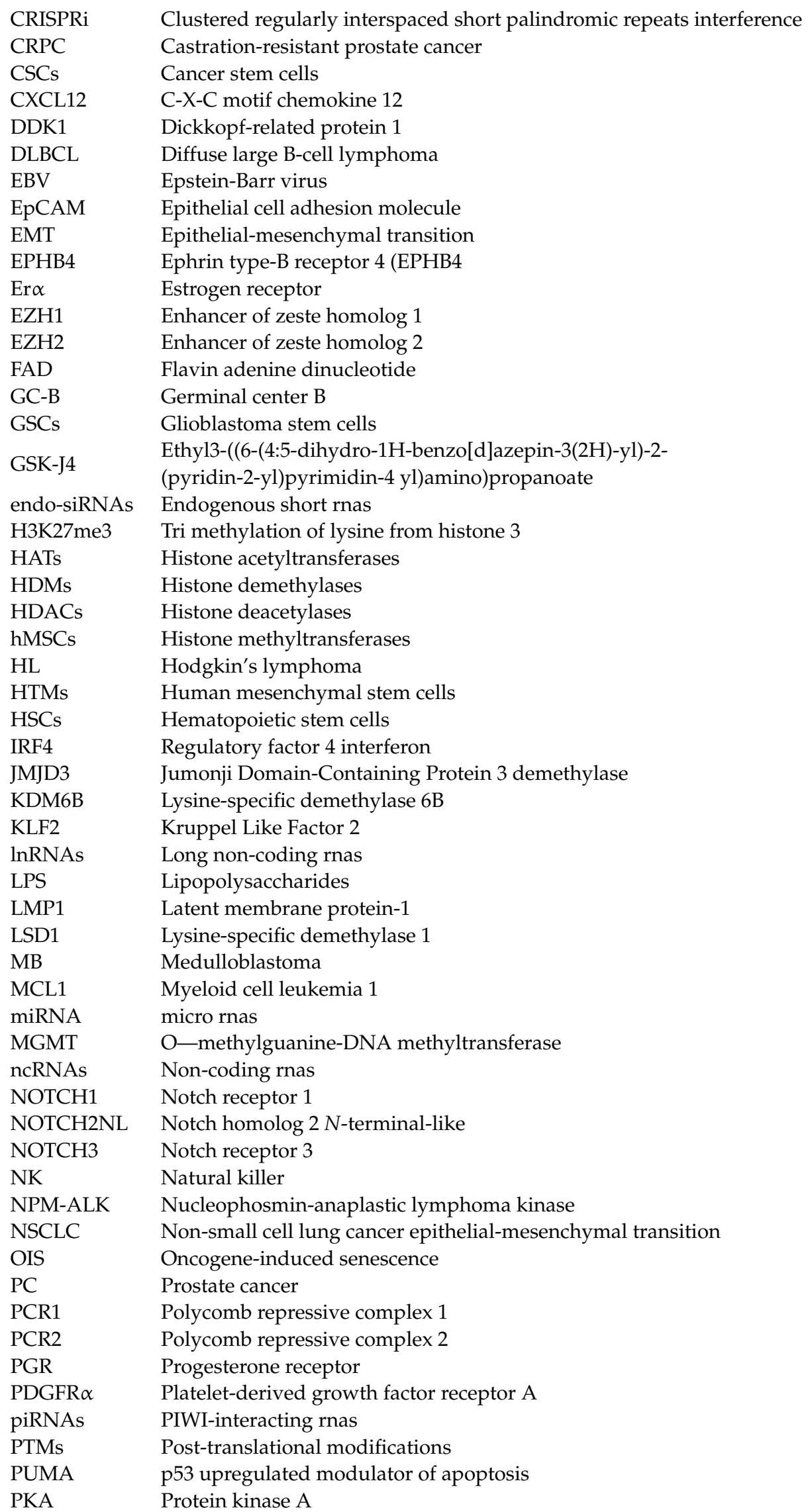




$\begin{array}{ll}\text { PZLF } & \text { Promyelocytic leukaemia zinc finger } \\ \text { RAR } \beta 2 & \text { Retinoic acid receptor } \beta 2 \\ \text { RGMA } & \text { Repulsive guidance molecule A } \\ \text { RPS6KA2 } & \text { Ribosomal protein S6 kinase A2 } \\ \text { RTK } & \text { Receptor tyrosine kinase } \\ \text { RUNX2 } & \text { Runt-related transcription factor } 2 \\ \text { S1PR1 } & \text { Sphingosine-1-Phosphate Receptor } 1 \\ \text { SNAI1 } & \text { Snail homolog 1 } \\ \text { STAT3 } & \text { Activator of transcription 3 } \\ \text { T-ALL } & \text { T-cell acute lymphoblastic leukaemia } \\ \text { TopoII } \beta & \text { Topoisomerase ii } \beta \\ \text { TRA2A } & \text { Transformer 2 alpha homolog } \\ \text { U2AF1 } & \text { 2 small nuclear RNA auxiliary factor 1 } \\ \text { USP7 } & \text { Ubiquitin-specific peptidase 7 } \\ \text { UTX } & \text { Ubiquitously repeat transcribed tetratricopeptide repeat on the X chromosome } \\ \text { XIAP } & \text { X-linked inhibitor of apoptosis } \\ \text { ZEB1 } & \text { Zinc finger E-box-binding homeobox } 1\end{array}$

\section{References}

1. Bray, F.; Ferlay, J.; Soerjomataram, I.; Siegel, R.L.; Torre, L.A.; Jemal, A. Global Cancer Statistics 2018: GLOBOCAN Estimates of Incidence and Mortality Worldwide for 36 Cancers in 185 Countries. CA Cancer J. Clin. 2018, 68, 394-424. [CrossRef] [PubMed]

2. Aguilera, O.; Fernández, A.F.; Muñoz, A.; Fraga, M.F. Epigenetics and Environment: A Complex Relationship. J. Appl. Physiol. 2010, 109, 243-251. [CrossRef] [PubMed]

3. Peschansky, V.J.; Wahlestedt, C. Non-Coding RNAs as Direct and Indirect Modulators of Epigenetic Regulation. Epigenetics 2014, 9, 3-12. [CrossRef] [PubMed]

4. Ballestar, E.; Esteller, M. Epigenetic Gene Regulation in Cancer. Adv. Genet. 2008, 61, 247-267. [CrossRef]

5. Brait, M.; Sidransky, D. Cancer Epigenetics: Above and Beyond. Toxicol. Mech. Methods 2011, 21, 275-288. [CrossRef]

6. Taby, R.; Issa, J.-P.J. Cancer Epigenetics. CA Cancer J. Clin. 2010, 60, 376-392. [CrossRef]

7. Audia, J.E.; Campbell, R.M. Histone Modifications and Cancer. Cold Spring Harb. Perspect Biol. 2016, 8. [CrossRef]

8. Hyun, K.; Jeon, J.; Park, K.; Kim, J. Writing, Erasing and Reading Histone Lysine Methylations. Exp. Mol. Med. 2017, 49, e324. [CrossRef]

9. Xiang, Y.; Zhu, Z.; Han, G.; Lin, H.; Xu, L.; Chen, C.D. JMJD3 Is a Histone H3K27 Demethylase. Cell Res. 2007, 17, 850-857. [CrossRef]

10. Wiles, E.T.; Selker, E.U. H3K27 Methylation: A Promiscuous Repressive Chromatin Mark. Curr. Opin. Genet. Dev. 2017, 43, 31-37. [CrossRef]

11. Bannister, A.J.; Kouzarides, T. Regulation of Chromatin by Histone Modifications. Cell Res. 2011, 21, 381-395. [CrossRef] [PubMed]

12. Kanwal, R.; Gupta, S. Epigenetic Modifications in Cancer. Clin. Genet 2012, 81, 303-311. [CrossRef] [PubMed]

13. Luger, K.; Mäder, A.W.; Richmond, R.K.; Sargent, D.F.; Richmond, T.J. Crystal Structure of the Nucleosome Core Particle at 2.8 A Resolution. Nature 1997, 389, 251-260. [CrossRef]

14. Fischle, W.; Wang, Y.; Allis, C.D. Histone and Chromatin Cross-Talk. Curr. Opin. Cell Biol. 2003, 15, 172-183. [CrossRef]

15. Klose, R.J.; Kallin, E.M.; Zhang, Y. JmjC-Domain-Containing Proteins and Histone Demethylation. Nat. Rev. Genet. 2006, 7, 715-727. [CrossRef] [PubMed]

16. Meng, Y.; Li, H.; Liu, C.; Zheng, L.; Shen, B. Jumonji Domain-Containing Protein Family: The Functions beyond Lysine Demethylation. J. Mol. Cell Biol. 2018, 10, 371-373. [CrossRef] [PubMed]

17. Cloos, P.A.C.; Christensen, J.; Agger, K.; Helin, K. Erasing the Methyl Mark: Histone Demethylases at the Center of Cellular Differentiation and Disease. Genes Dev. 2008, 22, 1115-1140. [CrossRef] [PubMed]

18. Walport, L.J.; Hopkinson, R.J.; Vollmar, M.; Madden, S.K.; Gileadi, C.; Oppermann, U.; Schofield, C.J.; Johansson, C. Human UTY(KDM6C) Is a Male-Specific Ne-Methyl Lysyl Demethylase. J. Biol. Chem. 2014, 289, 18302-18313. [CrossRef]

19. Hong, S.; Cho, Y.-W.; Yu, L.-R.; Yu, H.; Veenstra, T.D.; Ge, K. Identification of JmjC Domain-Containing UTX and JMJD3 as Histone H3 Lysine 27 Demethylases. Proc. Natl. Acad. Sci. USA 2007, 104, 18439-18444. [CrossRef]

20. Farquharson, K.L. A Novel Class of Histone Readers. Plant Cell 2018, 30, 262-263. [CrossRef]

21. Mozzetta, C.; Boyarchuk, E.; Pontis, J.; Ait-Si-Ali, S. Sound of Silence: The Properties and Functions of Repressive Lys Methyltransferases. Nat. Rev. Mol. Cell Biol. 2015, 16, 499-513. [CrossRef] [PubMed]

22. Jiang, W.; Wang, J.; Zhang, Y. Histone H3K27me3 Demethylases KDM6A and KDM6B Modulate Definitive Endoderm Differentiation from Human ESCs by Regulating WNT Signaling Pathway. Cell Res. 2013, 23, 122-130. [CrossRef] [PubMed]

23. Burgold, T.; Voituron, N.; Caganova, M.; Tripathi, P.P.; Menuet, C.; Tusi, B.K.; Spreafico, F.; Bévengut, M.; Gestreau, C.; Buontempo, S.; et al. The H3K27 Demethylase JMJD3 Is Required for Maintenance of the Embryonic Respiratory Neuronal Network, Neonatal Breathing, and Survival. Cell Rep. 2012, 2, 1244-1258. [CrossRef] [PubMed] 
24. Ye, L.; Fan, Z.; Yu, B.; Chang, J.; Al Hezaimi, K.; Zhou, X.; Park, N.-H.; Wang, C.-Y. Histone Demethylases KDM4B and KDM6B Promotes Osteogenic Differentiation of Human MSCs. Cell Stem. Cell 2012, 11, 50-61. [CrossRef]

25. Naruse, C.; Shibata, S.; Tamura, M.; Kawaguchi, T.; Abe, K.; Sugihara, K.; Kato, T.; Nishiuchi, T.; Wakana, S.; Ikawa, M.; et al. New Insights into the Role of Jmjd3 and Utx in Axial Skeletal Formation in Mice. FASEB J. 2017, 31, 2252-2266. [CrossRef]

26. Agrawal Singh, S.; Lerdrup, M.; Gomes, A.-L.R.; van de Werken, H.J.; Vilstrup Johansen, J.; Andersson, R.; Sandelin, A.; Helin, K.; Hansen, K. PLZF Targets Developmental Enhancers for Activation during Osteogenic Differentiation of Human Mesenchymal Stem Cells. Elife 2019, 8. [CrossRef]

27. Zhang, F.; Xu, L.; Xu, L.; Xu, Q.; Karsenty, G.; Chen, C.D. Histone Demethylase JMJD3 Is Required for Osteoblast Differentiation in Mice. Sci. Rep. 2015, 5, 13418. [CrossRef]

28. Zhang, F.; Xu, L.; Xu, L.; Xu, Q.; Li, D.; Yang, Y.; Karsenty, G.; Chen, C.D. JMJD3 Promotes Chondrocyte Proliferation and Hypertrophy during Endochondral Bone Formation in Mice. J. Mol. Cell Biol. 2015, 7, 23-34. [CrossRef]

29. Zhang, T.; Huang, K.; Zhu, Y.; Wang, T.; Shan, Y.; Long, B.; Li, Y.; Chen, Q.; Wang, P.; Zhao, S.; et al. Vitamin C-Dependent Lysine Demethylase 6 (KDM6)-Mediated Demethylation Promotes a Chromatin State That Supports the Endothelial-to-Hematopoietic Transition. J. Biol. Chem. 2019, 294, 13657-13670. [CrossRef]

30. Yu, S.-H.; Zhu, K.-Y.; Zhang, F.; Wang, J.; Yuan, H.; Chen, Y.; Jin, Y.; Dong, M.; Wang, L.; Jia, X.-E.; et al. The Histone Demethylase Jmjd3 Regulates Zebrafish Myeloid Development by Promoting Spi1 Expression. Biochim. Biophys. Acta Gene Regul. Mech. 2018, 1861, 106-116. [CrossRef]

31. Manna, S.; Kim, J.K.; Baugé, C.; Cam, M.; Zhao, Y.; Shetty, J.; Vacchio, M.S.; Castro, E.; Tran, B.; Tessarollo, L.; et al. Histone H3 Lysine 27 Demethylases Jmjd3 and Utx Are Required for T-Cell Differentiation. Nat. Commun. 2015, 6, 8152. [CrossRef] [PubMed]

32. De Santa, F.; Totaro, M.G.; Prosperini, E.; Notarbartolo, S.; Testa, G.; Natoli, G. The Histone H3 Lysine-27 Demethylase Jmjd3 Links Inflammation to Inhibition of Polycomb-Mediated Gene Silencing. Cell 2007, 130, 1083-1094. [CrossRef] [PubMed]

33. Kruidenier, L.; Chung, C.; Cheng, Z.; Liddle, J.; Che, K.; Joberty, G.; Bantscheff, M.; Bountra, C.; Bridges, A.; Diallo, H.; et al. A Selective Jumonji H3K27 Demethylase Inhibitor Modulates the Proinflammatory Macrophage Response. Nature 2012, 488, 404-408. [CrossRef] [PubMed]

34. Cribbs, A.; Hookway, E.S.; Wells, G.; Lindow, M.; Obad, S.; Oerum, H.; Prinjha, R.K.; Athanasou, N.; Sowman, A.; Philpott, M.; et al. Inhibition of Histone H3K27 Demethylases Selectively Modulates Inflammatory Phenotypes of Natural Killer Cells. J. Biol. Chem. 2018, 293, 2422-2437. [CrossRef] [PubMed]

35. Wijayatunge, R.; Liu, F.; Shpargel, K.B.; Wayne, N.J.; Chan, U.; Boua, J.-V.; Magnuson, T.; West, A.E. The Histone Demethylase Kdm6b Regulates a Mature Gene Expression Program in Differentiating Cerebellar Granule Neurons. Mol. Cell. Neurosci. 2018, 87, 4-17. [CrossRef] [PubMed]

36. Miller, S.A.; Mohn, S.E.; Weinmann, A.S. Jmjd3 and UTX Play a Demethylase-Independent Role in Chromatin Remodeling to Regulate T-Box Family Member-Dependent Gene Expression. Mol. Cell 2010, 40, 594-605. [CrossRef]

37. Miller, S.A.; Weinmann, A.S. Molecular Mechanisms by Which T-Bet Regulates T-Helper Cell Commitment. Immunol. Rev. 2010, 238, 233-246. [CrossRef]

38. Zhao, W.; Li, Q.; Ayers, S.; Gu, Y.; Shi, Z.; Zhu, Q.; Chen, Y.; Wang, H.Y.; Wang, R.-F. Jmjd3 Inhibits Reprogramming by Upregulating Expression of INK4a/Arf and Targeting PHF20 for Ubiquitination. Cell 2013, 152, 1037-1050. [CrossRef]

39. Hashizume, R.; Andor, N.; Ihara, Y.; Lerner, R.; Gan, H.; Chen, X.; Fang, D.; Huang, X.; Tom, M.W.; Ngo, V.; et al. Pharmacologic Inhibition of Histone Demethylation as a Therapy for Pediatric Brainstem Glioma. Nat. Med. 2014, 20, 1394-1396. [CrossRef]

40. Ramaswamy, V.; Remke, M.; Taylor, M.D. An Epigenetic Therapy for Diffuse Intrinsic Pontine Gliomas. Nat. Med. 2014, 20, 1378-1379. [CrossRef]

41. Sui, A.; Xu, Y.; Li, Y.; Hu, Q.; Wang, Z.; Zhang, H.; Yang, J.; Guo, X.; Zhao, W. The Pharmacological Role of Histone Demethylase JMJD3 Inhibitor GSK-J4 on Glioma Cells. Oncotarget 2017, 8, 68591-68598. [CrossRef] [PubMed]

42. Sui, A.; Xu, Y.; Yang, J.; Pan, B.; Wu, J.; Guo, T.; Shen, Y.; Guo, X. The Histone H3 Lys 27 Demethylase KDM6B Promotes Migration and Invasion of Glioma Cells Partly by Regulating the Expression of SNAI1. Neurochem. Int. 2019, 124, 123-129. [CrossRef] [PubMed]

43. Zou, S.; Zhang, D.; Xu, Z.; Wen, X.; Zhang, Y. JMJD3 Promotes the Epithelial-Mesenchymal Transition and Migration of Glioma Cells via the CXCL12/CXCR4 Axis. Oncol. Lett. 2019, 18, 5930-5940. [CrossRef] [PubMed]

44. Ryan, K.M.; Phillips, A.C.; Vousden, K.H. Regulation and Function of the P53 Tumor Suppressor Protein. Curr. Opin. Cell Biol. 2001, 13, 332-337. [CrossRef]

45. Huang, J.; Sengupta, R.; Espejo, A.B.; Lee, M.G.; Dorsey, J.A.; Richter, M.; Opravil, S.; Shiekhattar, R.; Bedford, M.T.; Jenuwein, T.; et al. P53 Is Regulated by the Lysine Demethylase LSD1. Nature 2007, 449, 105-108. [CrossRef]

46. Ene, C.I.; Edwards, L.; Riddick, G.; Baysan, M.; Woolard, K.; Kotliarova, S.; Lai, C.; Belova, G.; Cam, M.; Walling, J.; et al. Histone Demethylase Jumonji D3 (JMJD3) as a Tumor Suppressor by Regulating P53 Protein Nuclear Stabilization. PLoS ONE 2012, 7. [CrossRef]

47. Sherry-Lynes, M.M.; Sengupta, S.; Kulkarni, S.; Cochran, B.H. Regulation of the JMJD3 (KDM6B) Histone Demethylase in Glioblastoma Stem Cells by STAT3. PLoS ONE 2017, 12, e0174775. [CrossRef]

48. Regad, T. Targeting RTK Signaling Pathways in Cancer. Cancers 2015, 7, 1758-1784. [CrossRef]

49. Yoon, S.; Wu, X.; Armstrong, B.; Habib, N.; Rossi, J.J. An RNA Aptamer Targeting the Receptor Tyrosine Kinase PDGFR $\alpha$ Induces Anti-Tumor Effects through STAT3 and P53 in Glioblastoma. Mol. Ther. Nucleic. Acids 2019, 14, 131-141. [CrossRef] 
50. Millard, N.E.; De Braganca, K.C. Medulloblastoma. J. Child. Neurol. 2016, 31, 1341-1353. [CrossRef]

51. Shi, X.; Zhang, Z.; Zhan, X.; Cao, M.; Satoh, T.; Akira, S.; Shpargel, K.; Magnuson, T.; Li, Q.; Wang, R.; et al. An Epigenetic Switch Induced by Shh Signalling Regulates Gene Activation during Development and Medulloblastoma Growth. Nat. Commun. 2014, 5, 5425. [CrossRef] [PubMed]

52. Chen, J.; Zhao, J.; Zhou, X.; Liu, S.; Yan, Y.; Wang, Y.; Cao, C.; Han, S.; Zhou, N.; Xu, Y.; et al. Immunohistochemical Investigation of TopoII $\beta$, H3K27me3 and JMJD3 Expressions in Medulloblastoma. Pathol. Res. Pract. 2017, 213, 975-981. [CrossRef] [PubMed]

53. Kaczówka, P.; Wieczorek, A.; Czogała, M.; Książek, T.; Szewczyk, K.; Balwierz, W. The Role of N-Myc Gene Amplification in Neuroblastoma Childhood Tumour-Single-Centre Experience. Contemp. Oncol. 2018, 22, 223-228. [CrossRef]

54. Lochmann, T.L.; Powell, K.M.; Ham, J.; Floros, K.V.; Heisey, D.A.R.; Kurupi, R.I.J.; Calbert, M.L.; Ghotra, M.S.; Greninger, P.; Dozmorov, M.; et al. Targeted Inhibition of Histone H3K27 Demethylation Is Effective in High-Risk Neuroblastoma. Sci. Transl. Med. 2018, 10. [CrossRef]

55. Varambally, S.; Dhanasekaran, S.M.; Zhou, M.; Barrette, T.R.; Kumar-Sinha, C.; Sanda, M.G.; Ghosh, D.; Pienta, K.J.; Sewalt, R.G.A.B.; Otte, A.P.; et al. The Polycomb Group Protein EZH2 Is Involved in Progression of Prostate Cancer. Nature 2002, 419, 624-629. [CrossRef]

56. Daures, M.; Ngollo, M.; Judes, G.; Rifaï, K.; Kemeny, J.-L.; Penault-Llorca, F.; Bignon, Y.-J.; Guy, L.; Bernard-Gallon, D. The JMJD3 Histone Demethylase and the EZH2 Histone Methyltransferase in Prostate Cancer. OMICS 2016, 20, 123-125. [CrossRef]

57. Ngollo, M.; Lebert, A.; Dagdemir, A.; Judes, G.; Karsli-Ceppioglu, S.; Daures, M.; Kemeny, J.-L.; Penault-Llorca, F.; Boiteux, J.-P.; Bignon, Y.-J.; et al. The Association between Histone 3 Lysine 27 Trimethylation (H3K27me3) and Prostate Cancer: Relationship with Clinicopathological Parameters. BMC Cancer 2014, 14. [CrossRef]

58. Ngollo, M.; Lebert, A.; Daures, M.; Judes, G.; Rifai, K.; Dubois, L.; Kemeny, J.-L.; Penault-Llorca, F.; Bignon, Y.-J.; Guy, L.; et al. Global Analysis of H3K27me3 as an Epigenetic Marker in Prostate Cancer Progression. BMC Cancer 2017, 17. [CrossRef]

59. Daures, M.; Idrissou, M.; Judes, G.; Rifaï, K.; Penault-Llorca, F.; Bignon, Y.-J.; Guy, L.; Bernard-Gallon, D. A New Metabolic Gene Signature in Prostate Cancer Regulated by JMJD3 and EZH2. Oncotarget 2018, 9, 23413-23425. [CrossRef]

60. Ngollo, M.; Lebert, A.; Daures, M.; Penault-Llorca, F.; Bernard-Gallon, D.; Guy, L. Étude de la marque H3K27me3 à l'échelle du génome: Mise en place d'un profil épigénétique en fonction de l'agressivité du cancer de la prostate. Prog. Urol. 2015, 25, 757. [CrossRef]

61. Morozov, V.M.; Li, Y.; Clowers, M.M.; Ishov, A.M. Inhibitor of H3K27 Demethylase JMJD3/UTX GSK-J4 Is a Potential Therapeutic Option for Castration Resistant Prostate Cancer. Oncotarget 2017, 8, 62131-62142. [CrossRef] [PubMed]

62. Sanchez, A.; El Ouardi, D.; Zohra Houfaf Khoufaf, F.; Mouhamed, I.; Boisnier, T.; Penault-Llorca, F.; Bignon, Y.-J.; Guy, L.; Bernard-Gallon, D. JMJD3 Demethylase and Its Inhibitor GSK-J4 in the Regulation of MGMT, TRA2A, RPS6KA2 and U2AF1 Genes in Prostate Cancer Cell Lines. OMICS A J. Integr. Biol. 2020, 24. [CrossRef] [PubMed]

63. El Ouardi, D.; Idrissou, M.; Sanchez, A.; Penault-LLorca, F.; Guy, L.; Bignon, Y.-J.; Bernard-Gallon, D. The Inhibition of the Histone Methyltransferase EZH2 by DZNEP or SiRNA Demonstrates Its Involvement in MGMT, TRA2A, RPS6KA2, and U2AF1 Gene Regulation in Prostate Cancer. OMICS A J. Integr. Biol. 2020, 24, 116-118. [CrossRef] [PubMed]

64. Idrissou, M.; Daures, M.; Jemia, A.B.; Judes, G.; Rifaï, K.; Penault-Llorca, F.; Bignon, Y.-J.; Guy, L.; Bernard-Gallon, D. EZH2 Histone Methyltransferase and JMJD3 Histone Demethylase Implications in Prostate Cancer. OMICS 2017, 21, 751-753. [CrossRef]

65. Sun, D.; Layer, R.; Mueller, A.C.; Cichewicz, M.A.; Negishi, M.; Paschal, B.M.; Dutta, A. Regulation of Several Androgen-Induced Genes through the Repression of the MiR-99a/Let-7c/MiR-125b-2 MiRNA Cluster in Prostate Cancer Cells. Oncogene 2014, 33, 1448-1457. [CrossRef]

66. Tamgue, O.; Lei, M. Triptolide Promotes Senescence of Prostate Cancer Cells Through Histone Methylation and Heterochromatin Formation. Asian Pac. J. Cancer Prev. 2017, 18, 2519-2526. [CrossRef]

67. Jin, Q.; Martinez, C.A.; Arcipowski, K.M.; Zhu, Y.; Gutierrez-Diaz, B.T.; Wang, K.K.; Johnson, M.R.; Volk, A.G.; Wang, F.; Wu, J.; et al. USP7 Cooperates with NOTCH1 to Drive the Oncogenic Transcriptional Program in T-Cell Leukemia. Clin. Cancer Res. 2019, 25, 222-239. [CrossRef]

68. Ntziachristos, P.; Tsirigos, A.; Welstead, G.G.; Trimarchi, T.; Bakogianni, S.; Xu, L.; Loizou, E.; Holmfeldt, L.; Strikoudis, A.; King, B.; et al. Contrasting Roles of Histone 3 Lysine 27 Demethylases in Acute Lymphoblastic Leukaemia. Nature 2014, 514, 513-517. [CrossRef]

69. Tottone, L.; Zhdanovskaya, N.; Carmona Pestaña, Á.; Zampieri, M.; Simeoni, F.; Lazzari, S.; Ruocco, V.; Pelullo, M.; Caiafa, P.; Felli, M.P.; et al. Histone Modifications Drive Aberrant Notch3 Expression/Activity and Growth in T-ALL. Front. Oncol. 2019, 9, 198. [CrossRef]

70. Mallaney, C.; Ostrander, E.L.; Celik, H.; Kramer, A.C.; Martens, A.; Kothari, A.; Koh, W.K.; Haussler, E.; Iwamori, N.; Gontarz, P.; et al. Kdm6b Regulates Context-Dependent Hematopoietic Stem Cell Self-Renewal and Leukemogenesis. Leukemia 2019, 33, 2506-2521. [CrossRef]

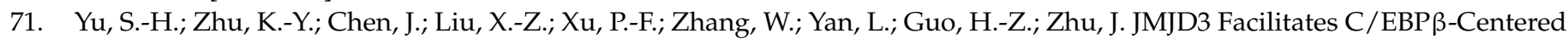
Transcriptional Program to Exert Oncorepressor Activity in AML. Nat. Commun. 2018, 9, 3369. [CrossRef] [PubMed]

72. Park, J.W.; Cho, H.; Oh, H.; Kim, J.-Y.; Seo, S.-B. AURKA Suppresses Leukemic THP-1 Cell Differentiation through Inhibition of the KDM6B Pathway. Mol. Cells 2018, 41, 444-453. [CrossRef] 
73. Illiano, M.; Conte, M.; Salzillo, A.; Ragone, A.; Spina, A.; Nebbioso, A.; Altucci, L.; Sapio, L.; Naviglio, S. The KDM Inhibitor GSKJ4 Triggers CREB Downregulation via a Protein Kinase A and Proteasome-Dependent Mechanism in Human Acute Myeloid Leukemia Cells. Front. Oncol. 2020, 10, 799. [CrossRef] [PubMed]

74. Illiano, M.; Conte, M.; Sapio, L.; Nebbioso, A.; Spina, A.; Altucci, L.; Naviglio, S. Forskolin Sensitizes Human Acute Myeloid Leukemia Cells to H3K27me2/3 Demethylases GSKJ4 Inhibitor via Protein Kinase A. Front. Pharmacol. 2018, 9, 792. [CrossRef] [PubMed]

75. Li, Y.; Zhang, M.; Sheng, M.; Zhang, P.; Chen, Z.; Xing, W.; Bai, J.; Cheng, T.; Yang, F.-C.; Zhou, Y. Therapeutic Potential of GSK-J4, a Histone Demethylase KDM6B/JMJD3 Inhibitor, for Acute Myeloid Leukemia. J. Cancer Res. Clin. Oncol.. 2018, 144, 1065-1077. [CrossRef]

76. Anderton, J.A.; Bose, S.; Vockerodt, M.; Vrzalikova, K.; Wei, W.; Kuo, M.; Helin, K.; Christensen, J.; Rowe, M.; Murray, P.G.; et al. The H3K27me3 Demethylase, KDM6B, Is Induced by Epstein-Barr Virus and over-Expressed in Hodgkin's Lymphoma. Oncogene 2011, 30, 2037-2043. [CrossRef]

77. Mathur, R.; Sehgal, L.; Havranek, O.; Köhrer, S.; Khashab, T.; Jain, N.; Burger, J.A.; Neelapu, S.S.; Davis, R.E.; Samaniego, F. Inhibition of Demethylase KDM6B Sensitizes Diffuse Large B-Cell Lymphoma to Chemotherapeutic Drugs. Haematologica 2017, 102, 373-380. [CrossRef]

78. Zhang, Y.; Shen, L.; Stupack, D.G.; Bai, N.; Xun, J.; Ren, G.; Han, J.; Li, L.; Luo, Y.; Xiang, R.; et al. JMJD3 Promotes Survival of Diffuse Large B-Cell Lymphoma Subtypes via Distinct Mechanisms. Oncotarget 2016, 7, 29387-29399. [CrossRef]

79. Xie, S.; Wei, F.; Sun, Y.-M.; Gao, Y.-L.; Pan, L.-L.; Tan, M.-J.; Wang, S.-D.; Ding, J.; Chen, Y. EZH2 Inhibitors Abrogate Upregulation of Trimethylation of H3K27 by CDK9 Inhibitors and Potentiate Its Activity against Diffuse Large B-Cell Lymphoma. Haematologica 2020, 105, 1021-1031. [CrossRef]

80. Martinelli, P.; Bonetti, P.; Sironi, C.; Pruneri, G.; Fumagalli, C.; Raviele, P.R.; Volorio, S.; Pileri, S.; Chiarle, R.; McDuff, F.K.E.; et al. The Lymphoma-Associated NPM-ALK Oncogene Elicits a P16INK4a/PRb-Dependent Tumor-Suppressive Pathway. Blood 2011, 117, 6617-6626. [CrossRef]

81. Tokunaga, R.; Sakamoto, Y.; Nakagawa, S.; Miyake, K.; Izumi, D.; Kosumi, K.; Taki, K.; Higashi, T.; Imamura, Y.; Ishimoto, T.; et al. The Prognostic Significance of Histone Lysine Demethylase JMJD3/KDM6B in Colorectal Cancer. Ann. Surg. Oncol. 2016, 23, 678-685. [CrossRef] [PubMed]

82. Pereira, F.; Barbáchano, A.; Silva, J.; Bonilla, F.; Campbell, M.J.; Muñoz, A.; Larriba, M.J. KDM6B/JMJD3 Histone Demethylase Is Induced by Vitamin D and Modulates Its Effects in Colon Cancer Cells. Hum. Mol. Genet. 2011, 20, 4655-4665. [CrossRef] [PubMed]

83. Pereira, F.; Barbáchano, A.; Singh, P.K.; Campbell, M.J.; Muñoz, A.; Larriba, M.J. Vitamin D Has Wide Regulatory Effects on Histone Demethylase Genes. Cell Cycle 2012, 11, 1081-1089. [CrossRef] [PubMed]

84. Nagarsheth, N.; Peng, D.; Kryczek, I.; Wu, K.; Li, W.; Zhao, E.; Zhao, L.; Wei, S.; Frankel, T.; Vatan, L.; et al. PRC2 Epigenetically Silences Th1-Type Chemokines to Suppress Effector T-Cell Trafficking in Colon Cancer. Cancer Res. 2016, 76, 275-282. [CrossRef]

85. Liao, M.-Y.; Kuo, M.Y.-P.; Lu, T.-Y.; Wang, Y.-P.; Wu, H.-C. Generation of an Anti-EpCAM Antibody and Epigenetic Regulation of EpCAM in Colorectal Cancer. Int. J. Oncol. 2015, 46, 1788-1800. [CrossRef]

86. Lian, H.; Jia, X.; Shi, N.; Xie, S.; Wang, J.; Wang, W.; Ma, F.; Liu, H.; Wang, A.; Cheng, X.; et al. Notch Signaling Promotes Serrated Neoplasia Pathway in Colorectal Cancer through Epigenetic Modification of EPHB2 and EPHB4. Cancer Manag Res. 2018, 10, 6129-6141. [CrossRef]

87. Falck, A.-K.; Fernö, M.; Bendahl, P.-O.; Rydén, L. St Gallen Molecular Subtypes in Primary Breast Cancer and Matched Lymph Node Metastases-Aspects on Distribution and Prognosis for Patients with Luminal A Tumours: Results from a Prospective Randomised Trial. BMC Cancer 2013, 13, 558. [CrossRef]

88. Svotelis, A.; Bianco, S.; Madore, J.; Huppé, G.; Nordell-Markovits, A.; Mes-Masson, A.-M.; Gévry, N. H3K27 Demethylation by JMJD3 at a Poised Enhancer of Anti-Apoptotic Gene BCL2 Determines ER $\alpha$ Ligand Dependency. EMBO J. 2011, 30, 3947-3961. [CrossRef]

89. Xun, J.; Wang, D.; Shen, L.; Gong, J.; Gao, R.; Du, L.; Chang, A.; Song, X.; Xiang, R.; Tan, X. JMJD3 Suppresses Stem Cell-like Characteristics in Breast Cancer Cells by Downregulation of Oct4 Independently of Its Demethylase Activity. Oncotarget 2017, 8, 21918-21929. [CrossRef]

90. Yan, N.; Xu, L.; Wu, X.; Zhang, L.; Fei, X.; Cao, Y.; Zhang, F. GSKJ4, an H3K27me3 Demethylase Inhibitor, Effectively Suppresses the Breast Cancer Stem Cells. Exp. Cell Res. 2017, 359, 405-414. [CrossRef]

91. Ramadoss, S.; Chen, X.; Wang, C.-Y. Histone Demethylase KDM6B Promotes Epithelial-Mesenchymal Transition. J. Biol. Chem. 2012, 287, 44508-44517. [CrossRef] [PubMed]

92. Prickaerts, P.; Adriaens, M.E.; van den Beucken, T.; Koch, E.; Dubois, L.; Dahlmans, V.E.H.; Gits, C.; Evelo, C.T.A.; Chan-Seng-Yue, M.; Wouters, B.G.; et al. Hypoxia Increases Genome-Wide Bivalent Epigenetic Marking by Specific Gain of H3K27me3. Epigenetics Chromatin 2016, 9, 46. [CrossRef] [PubMed]

93. Wei, Y.; Xia, W.; Zhang, Z.; Liu, J.; Wang, H.; Adsay, N.V.; Albarracin, C.; Yu, D.; Abbruzzese, J.L.; Mills, G.B.; et al. Loss of Trimethylation at Lysine 27 of Histone H3 Is a Predictor of Poor Outcome in Breast, Ovarian, and Pancreatic Cancers. Mol. Carcinog. 2008, 47, 701-706. [CrossRef] [PubMed] 
94. van den Beucken, T.; Koch, E.; Chu, K.; Rupaimoole, R.; Prickaerts, P.; Adriaens, M.; Voncken, J.W.; Harris, A.L.; Buffa, F.M.; Haider, S.; et al. Hypoxia Promotes Stem Cell Phenotypes and Poor Prognosis through Epigenetic Regulation of DICER. Nat. Commun. 2014, 5, 5203. [CrossRef]

95. Tian, C.; Deng, H.; Tang, X.; Hu, H.; Liu, X.; Luo, F. Effect of Jumonji domain-containing protein-3 on the proliferation and migration of lung cancer cell line. J. Biomed. Eng. 2012, 29, 514-518.

96. Zhang, Y.; Hua, P.-Y.; Jin, C.-Y.; Li, J.-D.; Zhang, G.-X.; Wang, B. JMJD3 Enhances Invasiveness and Migratory Capacity of Non-Small Cell Lung Cancer Cell via Activating EMT Signaling Pathway. Eur. Rev. Med. Pharmacol. Sci. 2019, $23,4784-4792$. [CrossRef]

97. Li, S.; Jiang, L.; He, Q.; Wei, W.; Wang, Y.; Zhang, X.; Liu, J.; Chen, K.; Chen, J.; Xie, D. The Prognostic Significance of JMJD3 In Primary Sarcomatoid Carcinoma Of The Lung, A Rare Subtype Of Lung Cancer. Onco Targets Ther. 2019, 12, 9385-9393. [CrossRef]

98. Ge, T.; Zhou, Y.; Lu, H. The Diagnostic Performance of Lysine(K)-Specific Demethylase 6B (KDM6B) in Non-Small Cell Lung Cancer. Artif. Cells Nanomed Biotechnol. 2019, 47, 2155-2160. [CrossRef]

99. Tang, B.; Qi, G.; Tang, F.; Yuan, S.; Wang, Z.; Liang, X.; Li, B.; Yu, S.; Liu, J.; Huang, Q.; et al. Aberrant JMJD3 Expression Upregulates Slug to Promote Migration, Invasion, and Stem Cell-Like Behaviors in Hepatocellular Carcinoma. Cancer Res. 2016, 76, 6520-6532. [CrossRef]

100. Zhang, P.-P.; Wang, X.-L.; Zhao, W.; Qi, B.; Yang, Q.; Wan, H.-Y.; Shuang, Z.-Y.; Liu, M.; Li, X.; Li, S.; et al. DNA MethylationMediated Repression of MiR-941 Enhances Lysine (K)-Specific Demethylase 6B Expression in Hepatoma Cells. J. Biol. Chem. 2014, 289, 24724-24735. [CrossRef]

101. Sakaki, H.; Okada, M.; Kuramoto, K.; Takeda, H.; Watarai, H.; Suzuki, S.; Seino, S.; Seino, M.; Ohta, T.; Nagase, S.; et al. GSKJ4, A Selective Jumonji H3K27 Demethylase Inhibitor, Effectively Targets Ovarian Cancer Stem Cells. Anticancer Res. 2015, 35, 6607-6614. [PubMed]

102. Liang, S.; Yao, Q.; Wei, D.; Liu, M.; Geng, F.; Wang, Q.; Wang, Y.-S. KDM6B Promotes Ovarian Cancer Cell Migration and Invasion by Induced Transforming Growth Factor-B1 Expression. J. Cell. Biochem. 2019, 120, 493-506. [CrossRef] [PubMed]

103. Mo, J.; Wang, L.; Huang, X.; Lu, B.; Zou, C.; Wei, L.; Chu, J.; Eggers, P.K.; Chen, S.; Raston, C.L.; et al. Multifunctional Nanoparticles for Co-Delivery of Paclitaxel and Carboplatin against Ovarian Cancer by Inactivating the JMJD3-HER2 Axis. Nanoscale 2017, 9, 13142-13152. [CrossRef] [PubMed]

104. Xu, Z.; Xia, Y.; Xiao, Z.; Jia, Y.; Li, L.; Jin, Y.; Zhao, Q.; Wan, L.; Yi, T.; Yu, Y.; et al. Comprehensive Profiling of JMJD3 in Gastric Cancer and Its Influence on Patient Survival. Sci. Rep. 2019, 9, 868. [CrossRef]

105. Zhang, G.; Xu, Y.; Zou, C.; Tang, Y.; Lu, J.; Gong, Z.; Ma, G.; Zhang, W.; Jiang, P. Long Noncoding RNA ARHGAP27P1 Inhibits Gastric Cancer Cell Proliferation and Cell Cycle Progression through Epigenetically Regulating P15 and P16. Aging 2019, 11, 9090-9110. [CrossRef]

106. Lhuissier, E.; Aury-Landas, J.; Allas, L.; Boittin, M.; Boumediene, K.; Baugé, C. Antiproliferative Effect of the Histone Demethylase Inhibitor GSK-J4 in Chondrosarcomas. IUBMB Life 2019, 71, 1711-1719. [CrossRef]

107. Pediconi, N.; Salerno, D.; Lupacchini, L.; Angrisani, A.; Peruzzi, G.; De Smaele, E.; Levrero, M.; Belloni, L. EZH2, JMJD3, and UTX Epigenetically Regulate Hepatic Plasticity Inducing Retro-Differentiation and Proliferation of Liver Cells. Cell Death Disease 2019, 10, 1-13. [CrossRef]

108. Lulla, R.R.; Saratsis, A.M.; Hashizume, R. Mutations in Chromatin Machinery and Pediatric High-Grade Glioma. Sci. Adv. 2016, 2, e1501354. [CrossRef]

109. Zhang, W.; Cheng, J.; Diao, P.; Wang, D.; Zhang, W.; Jiang, H.; Wang, Y. Therapeutically Targeting Head and Neck Squamous Cell Carcinoma through Synergistic Inhibition of LSD1 and JMJD3 by TCP and GSK-J1. Br. J. Cancer 2020, 122, 528-538. [CrossRef]

110. Rotili, D.; Tomassi, S.; Conte, M.; Benedetti, R.; Tortorici, M.; Ciossani, G.; Valente, S.; Marrocco, B.; Labella, D.; Novellino, E.; et al. Pan-Histone Demethylase Inhibitors Simultaneously Targeting Jumonji C and Lysine-Specific Demethylases Display High Anticancer Activities. J. Med. Chem. 2014, 57, 42-55. [CrossRef]

111. Giordano, A.; del Gaudio, F.; Johansson, C.; Riccio, R.; Oppermann, U.; Di Micco, S. Virtual Fragment Screening Identification of a Quinoline-5,8-dicarboxylic Acid Derivative as a Selective JMJD3 Inhibitor. ChemMedChem 2018, 13, 1160-1164. [CrossRef] [PubMed]

112. Giordano, A.; Forte, G.; Terracciano, S.; Russo, A.; Sala, M.; Scala, M.C.; Johansson, C.; Oppermann, U.; Riccio, R.; Bruno, I.; et al. Identification of the 2-Benzoxazol-2-Yl-Phenol Scaffold as New Hit for JMJD3 Inhibition. ACS Med. Chem. Lett. 2019, 10, 601-605. [CrossRef] [PubMed]

113. Basu Mallik, S.; Pai, A.; Shenoy, R.R.; Jayashree, B.S. Novel Flavonol Analogues as Potential Inhibitors of JMJD3 Histone Demethylase-A Study Based on Molecular Modelling. J. Mol. Graph. Model. 2017, 72, 81-87. [CrossRef] [PubMed]

114. Zhang, Y.; Lou, C.; Xu, Y.; Li, J.; Qian, S.; Li, F.; Kang, J. Screening of Inhibitors against Histone Demethylation Jumonji Domain-Containing Protein 3 by Capillary Electrophoresis. J. Chromatogr A 2020, 1613, 460625. [CrossRef] [PubMed] 